\title{
A study on impact of workplace spirituality on customer-oriented organizational citizenship behavior by considering the role of spiritual intelligence: A case study of an insurance company
}

\author{
Jaber Moghaddampour $^{a^{*}}$ and Mohammad Vazin Karimian ${ }^{\text {b }}$
}

${ }^{a}$ M. A. Public Administration, Faculty of Human Science, Shahed Universuty, Tehran, Iran

${ }^{b}$ Assistant Professor of Management, Faculty of Human Science, Shahed Universuty, Tehran, Iran

\section{H R O N I C L E}

Article history:

Received January 18, 2013

Received in revised format

10 May 2013

Accepted May 152013

Available online

May 162013

Keywords:

Psychological approach

Spirituality in workplace

Customer-oriented behavior

$C O-O C B$

\begin{abstract}
A B S T R A C T
Present study investigates the effect of workplace spirituality on customer-oriented organizational citizenship behavior by considering the role of spiritual intelligence. To measure the concepts of workplace spirituality, customer-oriented organizational citizenship behavior (CO-OCB) and spiritual intelligence, the conceptualizations are applied on 282 employees of an insurance company in Tehran during the fiscal year of 2011 and the results are analyzed using structural equation modeling. The findings reveal that spiritual intelligence and workplace spirituality have positive impact on customer-oriented organizational citizenship behavior. However, when spiritual intelligence is considered as a moderating factor, spirituality development in workplace cannot alone influence on customer-oriented organizational citizenship behavior since including spiritual intelligence hedges the effect of workplace spirituality on customer-oriented organizational citizenship behavior though workplace spirituality can improve customer-oriented organizational citizenship behavior through impacting on spiritual intelligence.
\end{abstract}

(C) 2013 Growing Science Ltd. All rights reserved.

\section{Introduction}

Most service organizations may forget about the reason they are built and the mission of their work. They may disregard that the survival any organization depends on customers and clients and all their activities should be accomplished towards their customers' needs satisfaction on received services and products quality. In fact, the primary objective of many organizations is often neglected in paramount bureaucratic structures and roles and, more importantly, lack of customer-orientation behaviors by their personnel. In this line, the practical action of employees is merit response to customers' requirements in order to attract their satisfaction, which requires appropriate employees' treatment with customers and helping colleagues in expressing customer-oriented behaviors (Ghaseminejad, 2008). According to Robbins (2005) "Today, for their success, organizations need 
employees who serve beyond their functions, that is, people who represent beyond expectation performance". Organizations need to express behaviors by their staff through interacting with their customers who are not officially prescribed by the organization but influence on the quality of delivering services to customers. Therefore, customer-oriented organizational citizenship behavior must be considered as a main concern of service organizations (McKenzie, 1997). On the other hand, the relative importance of spirituality and spiritual intelligence is another interesting issue (Rastegar, 2010). A powerful force impacts historic evolutions in management and organization arenas either theoretically or practically. This power is nothing rather than spirituality so that conducting it in the organization is considered as the most important future managerial initiative (Neal et al., 1999).

In recent decades, it was believed that this power in not only acceptable for business world (Conger, 1994) but also is uniquely admirable in ordinary literature (Mitroff \& Denton, 1999). However, this issue is now seriously investigated in many scientific scopes (Cornell, 1999) and it is nothing rather than spirituality so that conducting it in organization would be the most important future activity of management (Mitroff \& Denton, 1999). Since spirituality and spiritual intelligence play a essential role in generating the attitudes and values of people, it is important to study this concept in organizational literature. In other word, people enter into their workplace with something beyond their physical bony and thinking and bring their exclusive morale to their workplace (Saghravani \& Ghayour, 2009).

Concerning the relative importance of customer-oriented organizational citizenship behavior by employees and the emphasis of authors on addressing this issue in studies on service sector as well as the importance of conducting spirituality and spiritual intelligence in organization, the present research studies the impact of spiritual intelligence on customer - oriented organizational citizenship behavior by employees.

\section{Reviewing the literature}

\subsection{Customer - oriented behavior and its importance in the organization}

The increasingly importance of human resources and its role on organizational performance has led into many studies on employees' behavior as primary organizational source and capital. In most researches, the conclusion is that employees' behaviors are beyond what they do based on their terms of references and such behaviors impact on others' performance, customers' loyalty and organizational performance and success (Zarei Matin, 2009). Literature on good services reveal that employees render behaviors that are not officially necessary but they lead into customer satisfaction. These activities include helping customers through creative methods when some certain problems happen (Bitner et al., 1990; Carlson, 1987). They also help other people in the organization so that they could provide customers with excellent services (Gronroos, 1985) and represent creative suggestions to improve the quality (Bowen \& Lawler, 1992). Such behaviors are clarified as customer-oriented organizational citizenship behavior and they are similar to Organ's (1988) organizational citizenship behavior, which specifies that consciousness includes a visionary behavior expressed by the minimum legal requirements, philanthropy, helping other people in their organizational problems and civic behaviors. This tends to have an accountable contribution in organizational life (Dimitriades, 2007). Padsakoff and McKenzie (1997) divided employees' behaviors in terms of the orientation toward organizations, customers and their inter/cross-roles into five groups.

Table 1

Employees' behavior forms

\begin{tabular}{ccc}
\hline Behaviors & Orientation toward organization & Orientation toward customer \\
\hline Inter-role & Job and task - oriented behaviors & Service and sale - oriented behaviors \\
Cross-role & $\begin{array}{c}\text { Organizational citizenship behaviors } \\
\text { Contradictory citizenship behaviors }\end{array}$ & Customer - oriented behaviors \\
\hline
\end{tabular}


Considering such categorization of customer-oriented organizational citizenship behavior, cross-role is a behavior that its orientation is associated with both organization and customers. The findings of different researches demonstrate that organizations with customer-orientation compared with organizations without such orientation are more likely to satisfy their customers and meet their long terms aims (Brady \& Cornin, 2001). Searching relevant literature shows that expressing customeroriented behaviors would lead into profitable results for organization, customers and also employees and the results are summarized in Table 2.

\section{Table 2}

The results of expressing customer - oriented organizational citizenship behavior by employees

\begin{tabular}{|c|c|c|}
\hline For employees & For customers & For organization \\
\hline $\begin{array}{l}\text { Developing long term relations with } \\
\text { customer (Kelley, 1992) }\end{array}$ & $\begin{array}{l}\text { Rising customer satisfaction (Dunlap et } \\
\text { al, 1988) }\end{array}$ & $\begin{array}{c}\text { Employees' performance } \\
\text { improvement (Dimitriades, 2007) }\end{array}$ \\
\hline $\begin{array}{l}\text { Giving creative suggestions to } \\
\text { improve the quality by employees } \\
\text { (Bowen and Lawler, 1992) }\end{array}$ & $\begin{array}{l}\text { Developing long term relations with } \\
\text { organization (Kelley, 1992) }\end{array}$ & $\begin{array}{l}\text { Satisfaction feeling (Dimitriades, } \\
\text { 2007; Knox, 2007) }\end{array}$ \\
\hline $\begin{array}{l}\text { Service quality improvement } \\
\text { (Hartline et al, 2000) }\end{array}$ & $\begin{array}{l}\text { Improved service quality (Dimitriades, } \\
\text { 2007) }\end{array}$ & $\begin{array}{c}\text { Aiding each other in the organization } \\
\text { to provide excellent services } \\
\text { (Gronrros, 1985) }\end{array}$ \\
\hline $\begin{array}{l}\text { Higher profitability (Hartline et al, } \\
\text { 2000) }\end{array}$ & $\begin{array}{l}\text { Employees' aid to assess the needs ,to } \\
\text { make satisfied decisions and to meet } \\
\text { the needs (Hoffman \& Ingram, 1992) }\end{array}$ & \\
\hline
\end{tabular}

If customer-oriented organizational citizenship behavior improves perceptions on services quality and develops the relationship between customers and organization and, more importantly, customer satisfaction, the important question is that how can we encourage those employees who interact with customers in order to express such behavior? In present study, the impact of spirituality variable in workplace by considering the role of spiritual intelligence on the behaviors of an insurance company in Tehran is investigated.

\subsection{Spirituality in work and workplace}

There is a fact that mechanical paradigms do not always meet organizational expectations and demands have enforced organization to look for other techniques to achieve a competitive advantage. Furthermore, organizations are faced with experienced employees who demand meaningful and objective work and try to create favored workplaces for their progress (Rastegar, 2010). Hence, in order to meet employees' excellent we need to have newer and more comprehensive discussions on employees' behavior. There are some studies, which indicate that meeting employees' excellent needs are associated with spirituality-related models. Therefore, a new approach is to develop the grounds and workplaces so that they breed employees' personal creativity and growth and complete self-expression is possible by entering spirituality in organization (Kennedy, 2002). Spirituality in work and workplace describes the experiences of those employees who are energetic with high enthusiasm, they are satisfied with working conditions, they conceive meaning and aim in their life and they feel that they have effective relationships with their colleagues (Knijersky \& Skrypenk, 2004). Gibons (2000) stated that spiritualty in work involves a concept of integrity and community in work and understanding deep values of work.

In present study, the argument and concept of workplace spirituality is considered and all provided levels by Milliman et al. (2003) are utilized. In analyzing organizational spirituality levels, we continue the work accomplished earlier by Milliman et al. (Rastegar, 2010). Workplace spirituality consists of an attempt to find the ultimate objective in life, to develop strong relationship with colleagues and other relevant people in agreement with equilibrium in personal beliefs and organizational values (Mitroff \& Denton, 1999). Workplace spirituality is also defined as: "conceiving and identifying the fact that employees have an inner life which can be breed and 
enforced by a meaningful work in society" (Ashmos \& Duchon, 2000). One can find them clearly is provided levels by Milliman et al. (2003) as follows,

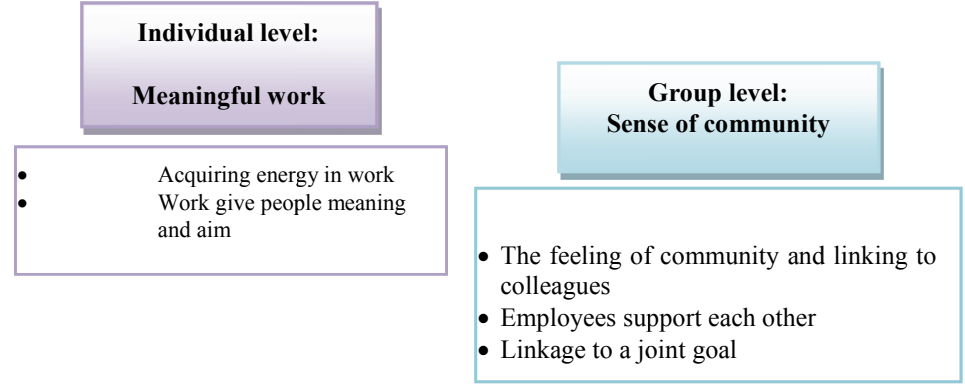

Fig. 1. Spirituality in organization by considering three Individual, group and organizational levels

\subsection{Spiritual intelligence: the capability of connection to self, connection to others and connection to transcendent}

Spiritual intelligence is a concept emerged in the light of global interest by psychologists to religion and spirituality. Spiritual intelligence is a new and interesting issue with rare theoretical materials and empirical findings (Sohrabi, 2008). During the past few years, the concept of spiritual intelligence concept has been under tremendous investigation after raising a new paradigm. Spiritual intelligence became popular by Harvard psychology professor Emmons (2000) and Zohar and Marshall (2000) as the innovators of using Quantum thinking in management and leadership (Vaughan, 2003). Along with emotional intelligence, physiological intelligence and cognitive intelligence, spiritual intelligence has been a subject of paramount researches. Four existential, social, mental and spiritual aspects are linked to four physiologic intelligence, emotional intelligence, cognitive intelligence and spiritual intelligence (Fontana, 2003). Spiritual intelligence incorporates a space (ground) where other types of intelligence performs better. Spiritual intelligence performs this task by inspirational and spiritual guides as well as generating creative thinking and a holistic approach (Zohar \& Marshall, 2000). If cognitive (rational) intelligence is about "thinking" and "emotional intelligence" is about "feeling", then spiritual intelligence will be on "being" (McMullen, 2003). One can apply spiritual intelligence to change and redefine events in life (Vaughan, 2003).

Neal (2004) stated that spiritual intelligence could start with self-awareness feeling and its five aspects including physical, rational, emotional, willful and spiritual. People with strong connection to self, relate to their values and beliefs with a strong degree of emotional intelligence. They are able to conduct spiritual activities and personal development initiatives so that they could dominate their thoughts, feelings and behavior. Other people discover themselves as people with strong connection to self and cold-blooded people who act competently in upset situation. According to Neal, self awareness and facing with personal growth is not sufficient alone. People with higher spiritual intelligence use such self - awareness as an underlay to understand other people better and to develop significant relationships. Among five work aspects, connection to others is more associated with emotional aspect due to its emphasis on workplace interpersonal dimensions. People with strong connection to others are too courteous concerning differences in values, believes and cultural themes and are more looking for knowing. They are able to forgive and treat anyone as a holy and unique entity. The main element, which may distinguish spiritual intelligence from other kinds of human intelligence is the emphasis on connection to transcendent that people may attribute to God, existence universe, transcendent or similar terms. Among five aspects of God including physical, rational, emotional, willful and spiritual, connection to transcendent is more associated with spiritual aspect because of its emphasis on the holiness of human and life. People who have strong connection to 
transcendent tend to have an explicit sense on their important targets and they address to ethical and spiritual discussions such as justice and respect.

\section{Methodology}

In present study, spirituality in work is considered as independent variable and customer-oriented organizational citizenship behavior as dependent one. Likewise, the moderator and/or mediating role of spiritual intelligence is also analyzed. Since in past researches the relationship between spiritual intelligence and customer-oriented organizational citizenship behavior was not discussed, by studying the relevant literature and rational believes following conceptual model is provided to recognize casual relations between spiritual intelligence and customer-oriented organizational citizenship behavior variables:

H 4.2

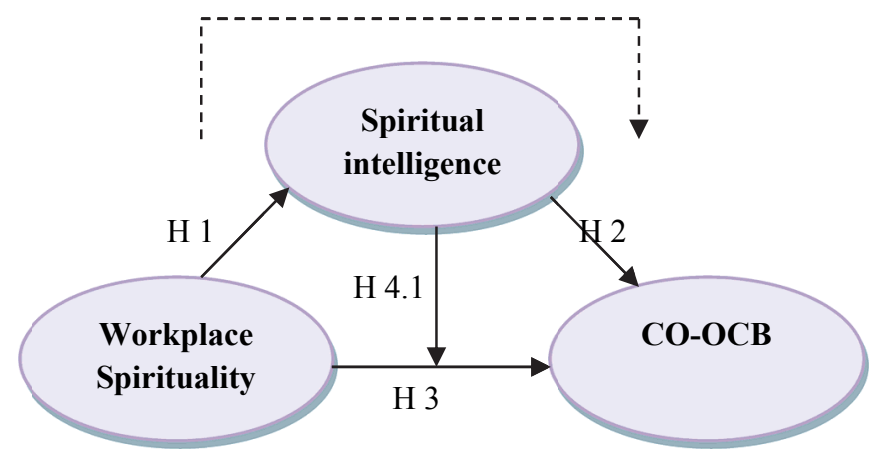

Fig. 2. Research conceptual model

Concerning the represented conceptual model, the following hypotheses are considered:

1. Workplace spirituality impacts on the spiritual intelligence of $\mathrm{X}$ insurance company employees positively.

2. Spiritual intelligence impacts on customer-oriented organizational citizenship behavior of $X$ insurance company employees positively.

3. Workplace spirituality impacts on the customer - oriented organizational citizenship behavior of $\mathrm{X}$ insurance company employees positively.

4.1. Spiritual intelligence moderates the relationship between workplace spirituality and customer oriented organizational citizenship behavior of X insurance company employees

4.2. Through spiritual intelligence, Workplace spirituality impacts on the customer - oriented organizational citizenship behavior of $\mathrm{X}$ insurance company employees positively (spiritual intelligence mediates in the relationship between workplace spirituality and customer - oriented organizational citizenship behavior).

The Present study is an applied one in terms of the objective and it is a descriptive one in terms of data collection method. Among survey techniques, periodical one is implemented and since the researcher attends in the real life conditions of an organization, present study is a field study. Finally, it is a correlation research since it looks for recognizing the relations among variables particularly based on structural equations and path analysis method. In researches that the authors plans to test a certain model in terms of relations between studied variables, structural equation model is used (Sarmad et al., 2008). Structural equation model is a comprehensive statistical approach, which tests hypotheses on relationships between observers and latent ones (Castro, 2004). The primary tools to gather information are library sources and questionnaire. Needed items to measure variables are extracted from previous researches. To measure customer-oriented organizational citizenship behavior, Dimitriade's questionnaire (2007) and to measure spiritual intelligence variable Neal's questionnaire are used. Customer-oriented organizational citizenship behavior questionnaire consists of 7 items devised by Likert seven - scale range. Spiritual intelligence questionnaire includes 30 items of which 10 items relate to the capability of connection to self, 10 items relate to the capability of connection to others and 10 items relate to the capability of connection to transcendent. It is devised based on Liker 5 - scale range. 
Initially, respondents were asked to answer questions on demographic factors such as age, gender, service years and education. The questionnaire was anonymous and closed one. To analyze gathered data, LISREL and SPSS 19 software were used. To analyze the validity of content, elites' opinions were collected. Furthermore, to confirm the validity, construct validity was analyzed by confirmatory factor analysis explained below. Chronbach's alpha was used to compute the reliability. To compute the reliability of questionnaires, one pretest was conducted so that 30 questionnaires were initially distributed and gathered in relevant population and after inserting the data the reliability ratio was computed by SPSS19 summarized in Table 3.

Table 3

Questionnaire reliability ratio

\begin{tabular}{|c|c|c|c|c|}
\hline Row & Questionnaire & Variable & $\begin{array}{c}\text { Reliability ratio of } \\
\text { variable }\end{array}$ & $\begin{array}{c}\text { Reliability ratio of } \\
\text { questionnaire }\end{array}$ \\
\hline 1 & Workplace spirituality & $\begin{array}{c}\text { Meaningful work } \\
\text { Sense of community } \\
\text { Homogenous values }\end{array}$ & $\begin{array}{l}0.915 \\
0.962 \\
0.938\end{array}$ & 0.952 \\
\hline 2 & $\begin{array}{c}\text { Customer - oriented } \\
\text { organizational citizenship } \\
\text { behavior }\end{array}$ & - & - & 0.901 \\
\hline 3 & Spiritual intelligence & $\begin{array}{l}\text { The ability of connection to self } \\
\text { The ability of connection to others } \\
\text { The ability of connection to transcendent }\end{array}$ & $\begin{array}{l}0.781 \\
0.808 \\
0.720\end{array}$ & 0.875 \\
\hline
\end{tabular}

It is said that if alpha is greater than 0.7, then test enjoys acceptable reliability (Momeni \& Ghayumi, 2010). As observed, the reliability ratio of customer - oriented organizational citizenship behavior is 0.901 and it is 0.875 for spiritual intelligence questionnaire that are all greater than 0.7 .

\subsection{Statistical population and sample}

Research population consists of all employees (996) at headquarters. To estimate the sample volume, Morgan's table is used in which the quantity of the sample is identified by the members of statistical population. The sample was determined by Morgan's table in a conservative manner. If the sample is computed by statistical formula, the figure is usually lower (Momeni \& Ghayumi, 2010). By using Morgan's table, volume sample was selected 278 subjects (Krejcie \& Morgan, 1970).

\section{Findings}

To analyze gathered data, a descriptive - inductive analysis was considered:

\subsection{Findings of descriptive analysis}

In our survey, 101 people representing $35.8 \%$ of the participants are male, 173 people representing $61.3 \%$ are female and the remaining $2.8 \%$ did not specify their genders. In terms of age, 81 participants representing $28.7 \%$ were about 30 years old, 145 people representing $51.4 \%$ were aged $30-40,51$ people representing $18.1 \%$ were aged $40-50$ and $1.8 \%$ did not specify any thing about their age. In terms of job experience, $4.6 \%$ of the participants had fewer than 1 year job experience, $12.4 \%$ of them had between 1 to 5 years of job experience, $30.1 \%$ maintained between 5 to 10 years of job experience, $11.3 \%$ of them had $11-15$ years of job experience, $4.6 \%$ of them had between 16-20 years of job experience, $4.6 \%$ has $21-25,3.5 \%$ had more than 25 years of job experience and $14.3 \%$ of them did not specify anything about their job experience. In terms of educational background, more than half of the participants had, at least, bachelor of science.

\subsection{Findings of inductive analysis}

To analyze inductive data, KMO test was initially used to study the sufficiency of sampling. The validity of spirituality constructs in workplace, customer-oriented organizational citizenship behavior, spiritual intelligence in work and their variables were studied by CFA as a special type of SEM. Spearman test was used to study the existence or nonexistence of correlation among variables and constituents. After confirming the correctness of measurement model and confirming the existence of correlation among variables, hypotheses were tested to which SEM was used which is a combination of path analysis graph and CFA. To evaluate the total fit, $x 2 / d f$, RMSEA, GFI and were utilized. 


\subsubsection{KMO test}

To study the sufficiency, KMO test is used (Habibpour, 2009). In Table 4, the results of KMO test for each variable are shown. As seen, it is obvious that all KMO test ratios are greater than 0.70 and are in desired level, which shows the sufficiency of sampling for factor analysis.

\section{Table 5}

The results of KMO test

\begin{tabular}{lc}
\hline Variable & KMO test \\
\hline Workplace spirituality & 0.896 \\
Customer - oriented organizational citizenship behavior & 0.840 \\
Spiritual intelligence & 0.763 \\
\hline
\end{tabular}

\subsubsection{Studying measurement models}

Before entering hypothesis test and conceptual model, it is necessary to confirm the correctness of measurement models. This will be accomplished by confirmatory factor analysis:

\subsubsection{Measuring model for customer - oriented organizational citizenship behavior}

Table 5 indicates the results of CFA on customer - oriented organizational citizenship behavior. As seen, all questions enjoy acceptable factor load. According to LISREL outcome, fit indicators of the model show that it is in a favorable situation in terms of tit indicators because that $\mathrm{x} 2 / \mathrm{df}$ is 2.46 which is lower than allowed rate (3) and RMSEA is also 0.055 which is lower than allowed rate $(0.08)$. Therefore, it does not need so amendment. P-value is 0.00000 which is lower than 0.050 .

Table 5

The results of CFA for question on Customer - oriented citizenship behavior

\begin{tabular}{|c|c|c|c|c|c|c|}
\hline Variable & Questions & T statistic & Significance level & Standard error & Factor load & $\mathrm{R}^{2}$ \\
\hline \multirow{7}{*}{$\begin{array}{l}\text { Customer - } \\
\text { oriented } \\
\text { organizational } \\
\text { citizenship } \\
\text { behavior }\end{array}$} & Q1 & 8.54 & $\mathrm{P}<.001$ & 0.070 & 0.507 & 0.257 \\
\hline & Q2 & 7.70 & $\mathrm{P}<.001$ & 0.077 & 0.463 & 0.214 \\
\hline & Q3 & 14.18 & $\mathrm{P}<.001$ & 0.077 & 0.758 & 0.574 \\
\hline & Q4 & 15.25 & $\mathrm{P}<.001$ & 0.075 & 0.797 & 0.636 \\
\hline & Q5 & 11.79 & $\mathrm{P}<.001$ & 0.077 & 0.660 & 0.436 \\
\hline & Q6 & 15.77 & $\mathrm{P}<.001$ & 0.072 & 0.816 & 0.666 \\
\hline & Q7 & 9.79 & $\mathrm{P}<.001$ & 0.082 & 0.569 & 0.324 \\
\hline
\end{tabular}

\subsubsection{Measurement model for workplace spirituality}

Table 6

The results of CFA on question concerning workplace spirituality variables

\begin{tabular}{|c|c|c|c|c|c|}
\hline Questions & Significance level & T statistic & Standard error & Factor load & $\mathbf{R}^{2}$ \\
\hline Q38 & --- & --- & --- & 0.775 & 0.601 \\
\hline Q39 & $\mathrm{P}<0.001$ & 14.24 & 0.075 & 0.831 & 0.69 \\
\hline Q40 & $\mathrm{P}<0.001$ & 11.6 & 0.072 & 0.69 & 0.476 \\
\hline Q41 & $\mathrm{P}<0.001$ & 12.04 & 0.085 & 0.713 & 0.508 \\
\hline Q42 & $\mathrm{P}<0.001$ & 10.8 & 0.06 & 0.647 & 0.419 \\
\hline Q43 & $\mathrm{P}<0.001$ & 7.31 & 0.061 & 0.451 & 0.203 \\
\hline Q44 & --- & --- & --- & 0.267 & 0.071 \\
\hline Q45 & $\mathrm{P}<0.001$ & 3.91 & 0.159 & 0.49 & 0.24 \\
\hline Q46 & $\mathrm{P}<0.001$ & 4.21 & 0.313 & 0.712 & 0.506 \\
\hline Q47 & $\mathrm{P}<0.001$ & 4.25 & 0.34 & 0.778 & 0.605 \\
\hline Q48 & $\mathrm{P}<0.001$ & 4.14 & 0.246 & 0.637 & 0.406 \\
\hline Q49 & $\mathrm{P}<0.001$ & 4.15 & 0.272 & 0.651 & 0.423 \\
\hline Q51 & --- & --- & $\overline{---}$ & 0.65 & 0.422 \\
\hline Q52 & $\mathrm{P}<0.001$ & 11.42 & 0.123 & 0.783 & 0.613 \\
\hline Q53 & $\mathrm{P}<0.001$ & 12.51 & 0.126 & 0.881 & 0.775 \\
\hline Q54 & $\mathrm{P}<0.001$ & 11.86 & 0.126 & 0.822 & 0.675 \\
\hline Q55 & $\mathrm{P}<0.001$ & 10.02 & 0.113 & 0.668 & 0.447 \\
\hline Q56 & $\mathrm{P}<0.001$ & 12.34 & 0.126 & 0.865 & 0.748 \\
\hline Q57 & $\mathrm{P}<0.001$ & 8.96 & 0.105 & 0.588 & 0.346 \\
\hline
\end{tabular}


According to Table 6, which shows the results of confirmatory factor analysis for workplace spirituality constituents, among studied questions, Q44 is deleted since its factor load is not acceptable. Table 7 indicates the results of CFA on workplace spirituality constituents. As seen. All constituents enjoy acceptable factor load. According to LISREL outcomes, fit indicators of the model show that it is in avorable situation in terms of fit indicators because that $\mathrm{x} 2 / \mathrm{df}$ is 2.66 which is lower than allowed rate (3) and RMSEA is also 0.024 which is lower than allowed rate $(0.08)$. Therefore, it does not need so amendments. P-value is 0.00000 which is lower than 0.050 .

Table 7

The results of CFA for the constituents of spiritual intelligence variable

\begin{tabular}{cccccccc}
\hline Variable & Questions & Significance level & T statistic & Standard error & Factor load & $\mathbf{R}^{2}$ \\
\hline \multirow{2}{*}{$\begin{array}{c}\text { workplace } \\
\text { spirituality }\end{array}$} & Meaningful work & $\mathrm{P}<0.001$ & 11.08 & 0.103 & 0.783 & 0.613 \\
& Sense of community & $\mathrm{P}<0.001$ & 4.25 & 0.229 & 0.972 & 0.945 \\
& Values homogeneity & $\mathrm{P}<0.001$ & 9.59 & 0.079 & 0.758 & 0.574 \\
\hline
\end{tabular}

\subsubsection{Measurement model for spiritual intelligence}

According to Table 8 which show the results of confirmatory factor analysis for spiritual intelligence constituents, among studied questions, Q11, Q12, Q17, Q22, Q26, Q27, Q30 and Q35 are deleted since their factor load or $\mathrm{t}$ statistic is not acceptable.

Table 8

The result of CFA on questions for spiritual intelligence constituents

\begin{tabular}{|c|c|c|c|c|c|c|}
\hline Variable & Questions & Significance level & T statistic & Standard error & Factor load & $\mathbf{R}^{2}$ \\
\hline \multirow{10}{*}{$\begin{array}{c}\text { Connection to } \\
\text { self }\end{array}$} & Q8 & --- & --- & --- & 0.463 & 0.215 \\
\hline & Q11 & $\mathrm{P}<.05$ & 2.02 & 0.062 & 0.125 & 0.015 \\
\hline & Q14 & $\mathrm{P}<.001$ & 5.52 & 0.054 & 0.4 & 0.16 \\
\hline & Q17 & $\mathrm{P}>.05$ & 1.17 & 0.072 & 0.072 & 0.005 \\
\hline & Q20 & $\mathrm{P}<.001$ & 6.54 & 0.08 & 0.525 & 0.271 \\
\hline & Q23 & $\mathrm{P}<.001$ & 4.36 & 0.072 & 0.314 & 0.086 \\
\hline & Q26 & $\mathrm{P}>.05$ & -0.714 & 0.069 & -0.043 & 0.001 \\
\hline & Q29 & $\mathrm{P}<.001$ & 7.09 & 0.078 & 0.604 & 0.365 \\
\hline & Q32 & $\mathrm{P}<.001$ & 7.12 & 0.081 & 0.609 & 0.371 \\
\hline & Q35 & $\mathrm{P}<.05$ & 2.14 & 0.074 & 0.133 & 0.017 \\
\hline \multirow{10}{*}{$\begin{array}{l}\text { Connection to } \\
\text { others }\end{array}$} & Q9 & --- & $\overline{---}$ & --- & 0.34 & 0.116 \\
\hline & Q12 & $\mathrm{P}>.05$ & 0.868 & 0.068 & 0.055 & 0.003 \\
\hline & Q15 & $\mathrm{P}<.001$ & 4.71 & 0.115 & 0.466 & 0.217 \\
\hline & Q18 & $\mathrm{P}<.001$ & -4.53 & 0.082 & -0.426 & 0.182 \\
\hline & Q21 & $\mathrm{P}<.001$ & 4.61 & 0.087 & 0.443 & 0.196 \\
\hline & Q24 & $\mathrm{P}<.001$ & 5.14 & 0.105 & 0.602 & 0.362 \\
\hline & Q27 & $\mathrm{P}<.01$ & 3.01 & 0.079 & 0.219 & 0.047 \\
\hline & Q30 & $\mathrm{P}<.01$ & 2.96 & 0.074 & 0.214 & 0.045 \\
\hline & Q33 & $\mathrm{P}<.001$ & 4.14 & 0.083 & 0.355 & 0.126 \\
\hline & Q36 & $\mathrm{P}<.001$ & 4.82 & 0.09 & 0.495 & 0.245 \\
\hline \multirow{10}{*}{$\begin{array}{l}\text { Connection to } \\
\text { transcendent }\end{array}$} & Q10 & --- & $\overline{---}$ & --- & 0.494 & 0.244 \\
\hline & Q13 & $\mathrm{P}<.001$ & 6.26 & 0.079 & 0.495 & 0.245 \\
\hline & Q16 & $\mathrm{P}<.001$ & 6.38 & 0.077 & 0.509 & 0.259 \\
\hline & Q19 & $\mathrm{P}<.001$ & 7.09 & 0.087 & 0.608 & 0.37 \\
\hline & Q22 & $\mathrm{P}>.05$ & 0.087 & 0.067 & 0.006 & 0 \\
\hline & Q25 & $\mathrm{P}<.001$ & 6.41 & 0.081 & 0.512 & 0.263 \\
\hline & Q28 & $\mathrm{P}<.001$ & 5.19 & 0.06 & 0.38 & 0.144 \\
\hline & Q31 & $\mathrm{P}<.001$ & 6.78 & 0.085 & 0.562 & 0.316 \\
\hline & Q34 & $\mathrm{P}<.001$ & 4.5 & 0.078 & 0.317 & 0.1 \\
\hline & Q37 & $\mathrm{P}<.001$ & 6.71 & 0.064 & 0.553 & 0.305 \\
\hline
\end{tabular}


Table 9 indicates the results of CFA on workplace spirituality constituents. As seen. All constituents enjoy acceptable factor load. According to LISREL outcomes, fit indicators of the model show that it is in a favorable situation in terms of fit indicators because that $\mathrm{x} 2 / \mathrm{df}$ is 2.25 which is lower than allowed rate (3) and RMSEA is also 0.045 which is lower than allowed rate $(0.08)$. Therefore, it does not need so amendments. Pvalue is 0.00000 which is lower than 0.050 .

\section{Table 9}

The results of CFA for the constituents of spiritual intelligence variable

\begin{tabular}{cccccccc}
\hline Variable & Questions & Significance level & T statistic & Standard error & Factor load & $\mathbf{R}^{2}$ \\
\hline $\begin{array}{c}\text { Spiritual } \\
\text { intelligence }\end{array}$ & $\begin{array}{c}\text { Connection to self } \\
\begin{array}{c}\text { Connection to } \\
\text { others }\end{array}\end{array}$ & $\mathrm{P}<.001$ & 8.23 & 0.132 & 1.09 & 1.19 \\
$\begin{array}{c}\text { Connection to } \\
\text { transcendent }\end{array}$ & $\mathrm{P}<.001$ & 5.54 & 0.18 & 0.997 & 0.994 \\
\hline
\end{tabular}

\subsubsection{Pearson test}

Before testing the hypotheses and identifying the impact or non-impact of variables on each other, it should be determined whether there is a correlation among research variables or not. To study the correlation among research variables, Pearson correlation coefficient is used. As seen in Table 10, there is correlation among research variables.

\section{Table 11}

Pearson correlation coefficient among variables

\begin{tabular}{|c|c|c|c|c|c|c|c|c|c|}
\hline Variables & 1 & 2 & 3 & 4 & 5 & 6 & 7 & 8 & 9 \\
\hline Meaningful work & 1 & - & - & - & - & - & - & - & - \\
\hline Sense of community & $0.655^{\star \star}$ & 1 & - & - & - & - & - & - & - \\
\hline Values homogeneity & $0.584^{\star \star}$ & $0.667^{\star \star}$ & 1 & - & - & - & - & - & - \\
\hline workplace spirituality & $0.862^{\star *}$ & $0.875^{\star \star}$ & $0.872^{\star \star}$ & 1 & - & - & - & - & - \\
\hline $\mathrm{CO}-\mathrm{OCB}$ & $0.363^{\star *}$ & $0.366^{* *}$ & $0.308^{\star \star}$ & $0.396^{\star *}$ & 1 & - & - & - & - \\
\hline Connection to self & $0.412^{\star \star}$ & $0.470^{* *}$ & $0.320^{\star *}$ & $0.455^{* *}$ & $0.478^{* *}$ & 1 & - & - & - \\
\hline Connection to transcendent & $0.434^{\star \star}$ & $0.470^{\star \star}$ & $0.334^{\star \star}$ & $0.470^{\star *}$ & $0.452^{\star \star}$ & $0.615^{\star *}$ & 1 & - & - \\
\hline Connection to transcendent & $0.446^{* *}$ & $0.404^{* *}$ & $0.313^{\star *}$ & $0.444^{* *}$ & $0.472^{* *}$ & $0.641^{\star *}$ & $0.548^{* *}$ & 1 & - \\
\hline Spiritual intelligence & $0.503^{\star \star}$ & $0.519^{\star *}$ & $0.375^{\star \star}$ & $0.531^{* *}$ & $0.546^{* *}$ & $0.873^{\star *}$ & $0.826^{* *}$ & $0.870^{\star *}$ & 1 \\
\hline
\end{tabular}

\subsubsection{Testing the hypotheses}

After assuring the rightness of measurement models and the existence of correlation among variables, hypotheses are tested. In all hypotheses, $\mathrm{H}_{0}$ is lack of impact by one variable on another variable and $\mathrm{H}_{1}$ is the impact of one variable on another one.

$$
\left\{\begin{array}{l}
H_{0}: \beta=0 \\
H_{1}: \beta \neq 0
\end{array}\right.
$$

To study the relationship between variables, multivariable analysis is used. In this end, SEM and path analysis are used. Noteworthy, hypotheses were tested by path ratio, $t$ statistic and significance level. The results of SEM and path analysis are as follow:

\subsubsection{Testing the $1^{\text {st }}$ hypothesis}

According to estimation model of the impact of workplace spirituality on spiritual intelligence and based on path ratio (0.646) between workplace spirituality and spiritual intelligence and also t statistic $(9.45)$, the $1^{\text {st }}$ hypothesis is confirmed. 


\section{Table 12}

The results of testing the first hypothesis

\begin{tabular}{|c|c|c|c|c|c|}
\hline $1^{\text {st }}$ hypothesis & Path ratio & T statistic & Sig & Standard error & Result \\
\hline $\begin{array}{l}\text { The positive impact of workplace spirituality on } \\
\text { spiritual intelligence }\end{array}$ & 0.646 & 9.45 & $\mathrm{P}<.001$ & 0.068 & Confirmed \\
\hline
\end{tabular}

\subsubsection{Testing the $2^{\text {nd }}$ hypothesis}

According to estimation model of the impact of workplace spirituality on customer - oriented organizational citizenship behavior and based on path ratio (0.615) between workplace spirituality and customer - oriented organizational citizenship behavior and also $t$ statistic (7.04), the $2^{\text {nd }}$ hypothesis is confirmed.

Table 13

The results of testing the second hypothesis

\begin{tabular}{|c|c|c|c|c|c|}
\hline $2^{\text {nd }}$ hypothesis & Path ratio & T statistic & Sig & Standard error & Result \\
\hline $\begin{array}{l}\text { The positive impact of spirituality intelligence on } \\
\text { customer-oriented organizational citizenship } \\
\text { behavior }\end{array}$ & 0.615 & 7.04 & $\mathrm{P}<.001$ & 0.087 & Confirmed \\
\hline
\end{tabular}
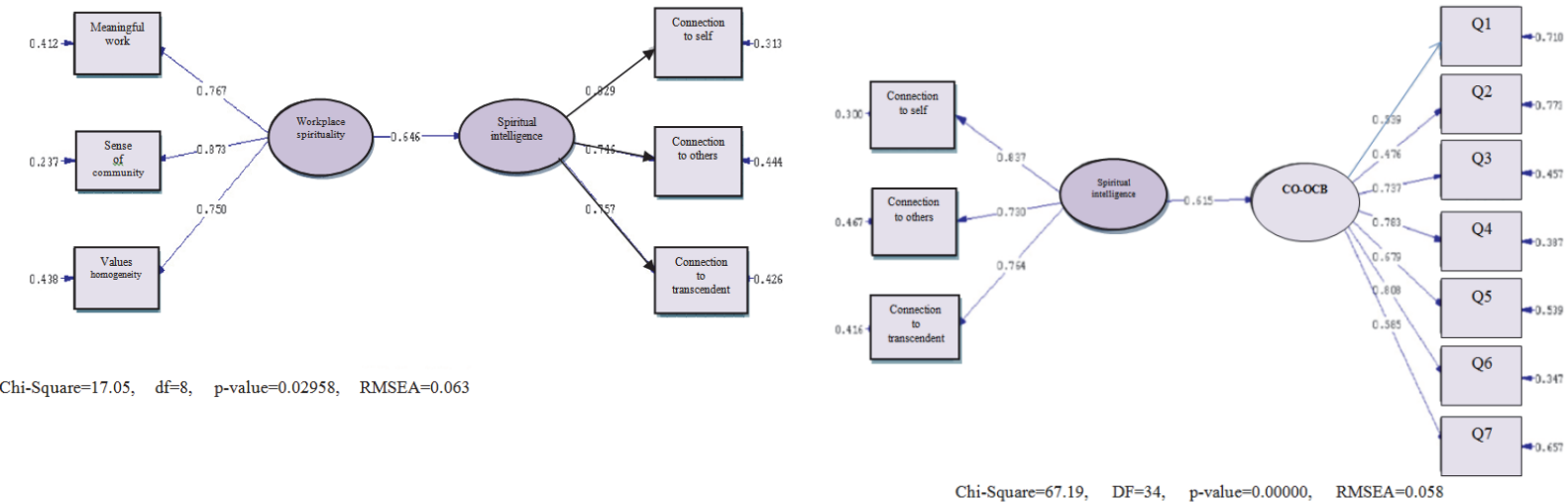

Fig. 3. the estimation model of the impact by "workplace spirituality" on "spiritual intelligence"

Fig. 4. the estimation model of the impact by "spiritual intelligence" on "customer-oriented organizational citizenship behavior"

\subsubsection{Testing the $3^{\text {rd }}$ hypothesis}

As seen in Table 13, path ratio between workplace spirituality and customer - oriented organizational citizenship behavior is 0.475 and $t$ statistic is acceptable. Therefore, the $3^{\text {rd }}$ hypothesis is confirmed.

\section{Table 13}

The results of testing the third hypothesis

\begin{tabular}{llllll}
\hline $3^{\text {rd }}$ hypothesis & Path ratio & T statistic & Sig & Standard error & Result \\
\hline $\begin{array}{l}\text { The positive impact of workplace spirituality on } \\
\text { customer }- \text { oriented organizational citizenship } \\
\text { behavior }\end{array}$ & & 5.475 & $\mathrm{P}<.001$ & 0.082 & Confirmed \\
\hline
\end{tabular}

\subsubsection{Testing the hypothesis 4.1}

According to Table 14, the extent of impact by workplace spirituality on customer - oriented organizational citizenship behavior is equal to 0.475 , which is moderated to 0.132 by inserting spiritual intelligence variable and in fact, at $95 \%$ confidence level, the impact of workplace spirituality on customer - oriented organizational citizenship behavior will become meaningless. Therefore, one can conclude that in $95 \%$ confidence level, 
hypothesis 4.1 is confirmed. In fact, spiritual intelligence moderates the relationship between workplace spirituality and customer - oriented organizational citizenship behavior of $\mathrm{X}$ insurance company personnel.

\section{Table 14}

The steps of testing hypothesis 4.1

\begin{tabular}{llllll}
\hline & $3^{\text {rd }}$ hypothesis & Path ratio & T statistic & Sig & Standard error \\
\hline Step 1 & $\begin{array}{l}\text { The positive impact of workplace spirituality on } \\
\text { customer-oriented organizational citizenship } \\
\text { behavior }\end{array}$ & & 5.475 & $\mathrm{P}<.001$ & 0.082 \\
Step 2 & $\begin{array}{l}\text { The positive impact of workplace spirituality on } \\
\text { customer-oriented organizational citizenship } \\
\text { behavior after inserting spiritual intelligence }\end{array}$ & & 1.52 & $\mathrm{p}>.05$ & 0.087 \\
\hline
\end{tabular}

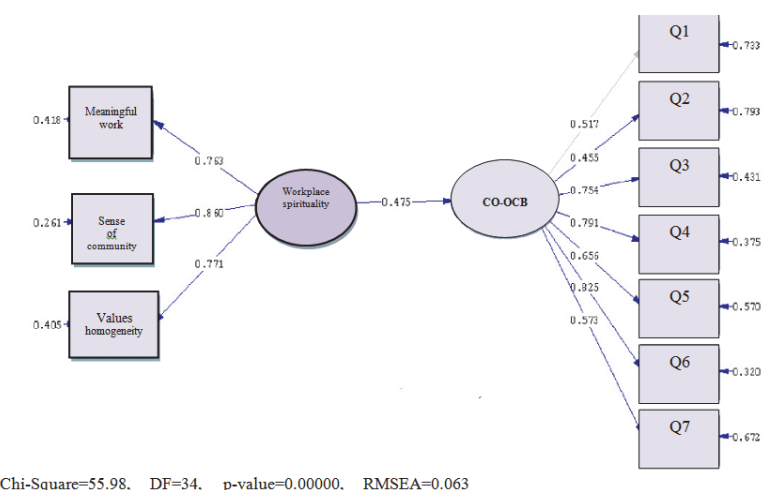

Chi-Square $=55.98, \quad \mathrm{DF}=34, \quad \mathrm{p}$-value $=0.00000, \quad$ RMSEA $=0.063$

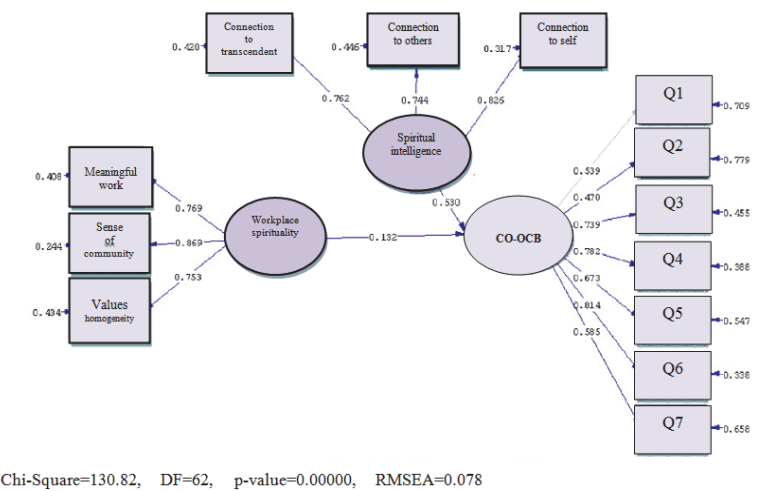

Chi-Square $=130.82, \quad$ DF $=62, \quad \mathrm{p}$-value $=0.00000, \quad$ RMSEA $=0.078$
Fig. 5. The estimation model of the impact by "spirituality in work" on "customer - oriented organizational citizenship behavior"
Fig. 6. the estimation model of the impact by "spirituality in work" on "customer-oriented organizational citizenship behavior" through moderating role of "spiritual intelligence"

\subsubsection{Testing the hypothesis 4.2}

According to table 16, the extent of impact by workplace spirituality on customer - oriented organizational citizenship behavior through spiritual intelligence is 0.415 . This figure is achieved through multiplying the path ratio of the impact of spirituality on spiritual intelligence $(0.660)$ in the path ratio of the impact of spiritual intelligence on customer - oriented organizational citizenship behavior (0.630).

\section{Table 15}

Testing hypothesis 4.2

\begin{tabular}{lll}
\hline Hypothesis 4.2 & Path ratio & Result \\
\hline $\begin{array}{l}\text { The positive impact of workplace spirituality on CO-OCB through } \\
\text { spiritual intelligence }\end{array}$ & $0.660 \times 0.630=0.415$ & Confirmed \\
\hline
\end{tabular}

Significant figures of general model and estimating the impact of general model are shown in Fig. 8 and Fig. 9. As seen, workplace spirituality impacts on organizational citizenship behavior only through spiritual intelligence and it has no impact if spiritual intelligence participates directly as a moderating variable. Fit indicators of the model show that it is in a favorable situation because that $\mathrm{x} 2 / \mathrm{df}$ is 2.11 which is lower than allowed rate (3) and RMSEA is also 0.058 which is lower than allowed rate (0.08). Therefore, it does not need so amendments. P-value is 0.00000 which is lower than 0.050 . In the meantime, significant figures of model parameters are greater than 1.96 . 


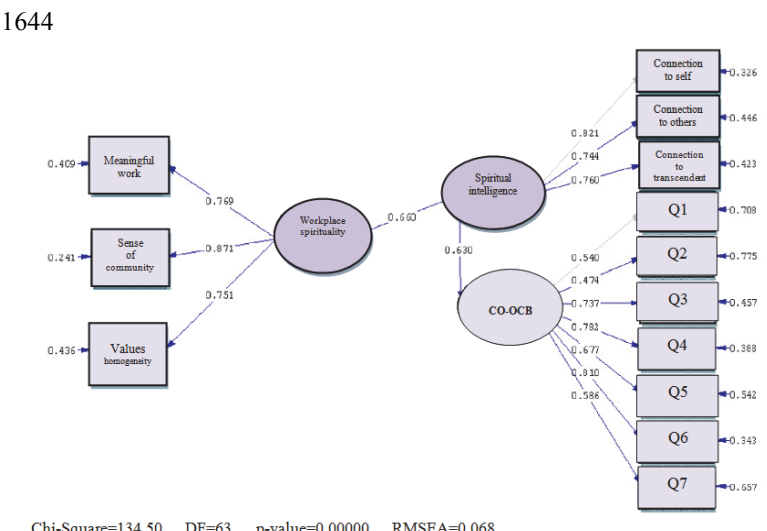

Chi-Squarc $=134.50, \quad \mathrm{DF}=63, \quad \mathrm{p}$-valuc $=0.00000, \quad \mathrm{RMSEA}=0.068$

Fig. 7. The estimation model of the impact by "spirituality in work" on "customer - oriented organizational citizenship behavior" through "spiritual intelligence" path

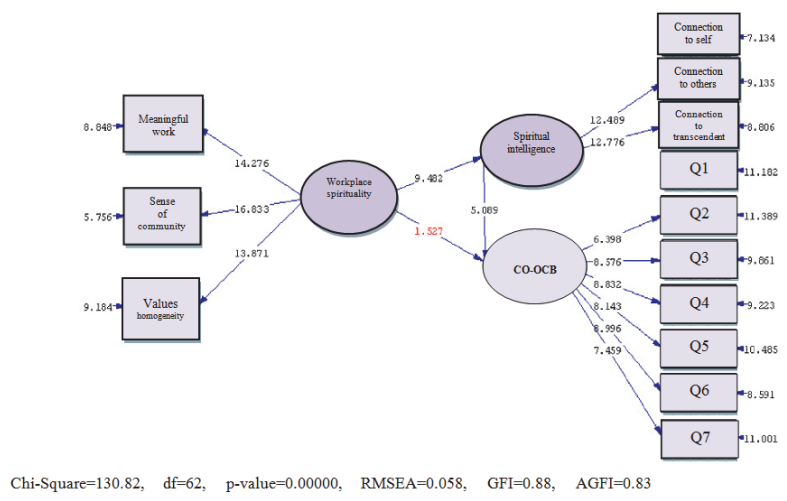

Fig. 8. General model significant figures

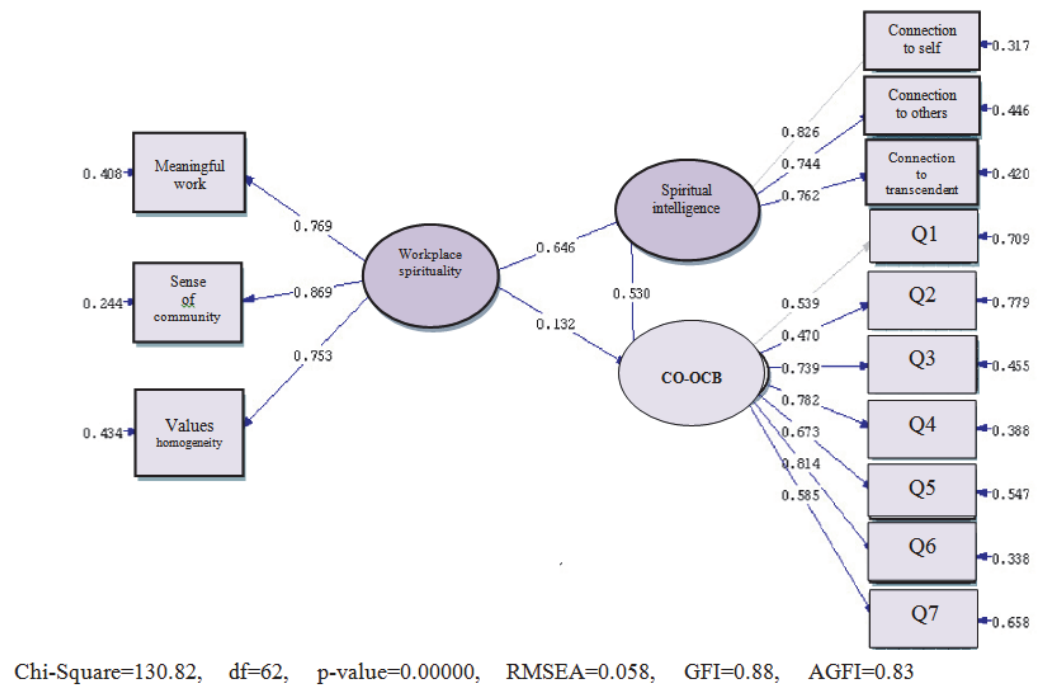

Fig. 9. The estimation of general model impact

\section{Discussion and recommendation}

\subsection{The results of the $1^{\text {st }}$ hypothesis}

Based on the result of testing the first hypothesis, workplace spirituality impacts on the spiritual intelligence of $X$ insurance company employees positively (0.646). As seen in literature, spirituality in work and organization is the breeding and monitoring on establishing four kinds of cross personal, intra-persona, interpersonal and outer-personal relations that cause employees have meaningful works, feel community with everything (Rastegar, 2010), develop strong relations with colleagues and other work related individuals and make a balance between personal beliefs and organizational values (Mitroff \& Dentone, 1999). It is clearly observed that all these four relations are rendered in spiritual intelligence variables including connection to self, connection to others and connection to transcendent. Thus, one can expect that employees' spiritual intelligence improve by the growth and development of workplace spirituality.

In one hand, Vaughan (2003) says that spiritual intelligence is a kind of intelligence by which we can give meaning to our actions. It can relate to meaningful work aspect of workplace spirituality. Sisk (2008) says that the feeling of connection to others is another trait of spiritual intelligence, which is clearly associated with correlation feeling with other. He also believes that sensitivity to life goals is 
another trait of spiritual intelligence. It seems that values homogeneity and personal/organizational aims impact on this trait of spiritual intelligence and leads into spiritual intelligence growth.

Due to extraordinary influence by spiritual intelligence on such variables as leadership, motivation, self - control, change capability, telecommunication and performance (Farhangi et al., 2009), one should attempt to grow spiritual intelligence of human resources as an important issue in management and organization. To grow employees' spiritual intelligence, it is suggested that managers attempt to improve spirituality in both personal and organizational levels. In fact, managers should pay attention to spiritual needs of people and try to create a dynamic and motivating organizational climate. The can improve employee' understanding in workplace through initiative such as job turnover, job enrichment, employees' improvement and making the job enjoyable (Farhangi et al., 2006).

Creating a friendly climate based on cooperation rather than competition can decrease employees' stress and create a kind of social capital in the organization and also increase the feeling of community and cohesion of employees (Farhangi et al., 2006). Elucidating a clear mission and perspective employees by managers, asking employees' opinions on values of the organization and respecting the health, morale and life conditions of employees can lead into more acceptances of organizational aims and values by employees (Farhangi et al., 2006).

\subsection{Results of the second hypothesis}

Based on the result of testing the second hypothesis, spiritual intelligence impacts on the organizational citizenship behavior of $X$ insurance company employees positively (0.615). The result of statistical test is in line with literature. Sisk (2008) says that valuing kindness and concern about others are the traits of spiritual intelligence. It seems that this trait impacts on altruism and leads into customer - oriented organizational citizenship behavior by employees. Also, George (2006) states the traits of people with spiritual intelligence as below: they like to serve other people and know that the only way to expand the capacity of their character is through serving other people. They consider their work as an arena to express their own creativity and their money is a side reward for them. Usually, they accept the responsibility of their works. Such issues indicate the consciousness and civilized behavior of organizational citizenship behavior and it seems that by impacting on consciousness and civilized behavior, spiritual intelligence leads into employees' customer - oriented organizational citizenship behavior.

Since spiritual intelligence is an aspect of spirituality application (Farhangi et al, 2009). To enhance spiritual intelligence, managers are suggested to improve their employees' spirituality. This kind of spirituality can based on such principles as love to other people, holistic and systemic thinking, the feeling of holiness in all jobs, awareness and praying the God for individual and organizational life gifts, the permission to conduct spiritual exercises and meetings to revise organizational initiatives spiritually. Such kind of spirituality can be not unique to religious people and involves all levels of the organization (Farhangi et al., 2009). Enhancing and encouraging ethical behaviors, breeding employees' self - awareness (Vaughan, 2003), paving the ground for interpersonal effective relations (Rastegar, 2010), creating the morale of compatibility with events and experiences, expanding the ideas and providing a ground to represent different viewpoints (Nasel, 2004), encouraging empathic behaviors toward colleagues (Vaughan, 2003), creating the morale to ask questions, developing the morale of thinking, paving the ground to learn from mistakes (Nasel, 2004) are, inter alia, initiatives suggested to grow employees' spiritual

Likewise, the employees of the company are proposed to respect changes in affection shape. Sympathy in relations to others (Vaughan, 2003), high sensation to spiritual issues, looking for the real meaning of facts and asking "why" questions for problems and honesty (Nasel, 2004) in order to grow their spiritual intelligence. 


\subsection{Results of the third hypothesis}

Based on the result of testing the third hypothesis, workplace spirituality impacts on the organizational citizenship behavior of $X$ insurance company employees positively (0.475). The results of past studies (Farhangi et al, 2006; Fatahi, 2007; Yazdani, 2010) confirm the results of the third hypothesis. The results of these studies confirm the role of workplace spirituality as a strong predictor of strong organizational citizenship behavior. As mentioned before, those activities that show customer - oriented organizational citizenship behavior are similar to three aspects of Organ's (1988) citizenship behavior including consciousness, altruism and civil behavior (Dimitriade, 2007). Farhangi et al. (2006) have confirmed a direct relationship between workplace spirituality and consciousness, altruism and civil behavior. Therefore, workplace spirituality development through impacting on mentioned organizational citizenship behavior can lead into customer - oriented organizational citizenship behavior by employees. Based on the results of the third hypothesis, another way to increase the expression of customer - oriented organizational citizenship behavior by employees is to respect workplace spirituality. Here, managers are also recommended to implement mechanisms explained to develop workplace spirituality.

\subsection{Results of hypotheses $4.1 \& 4.2$}

Based on the results of testing hypothesis 4.1, spiritual intelligence moderates the relationship between workplace spirituality and customer - oriented organizational behavior of $\mathrm{X}$ insurance company employees. Based on the conclusion of testing the third hypothesis, the extent of impact by workplace spirituality on organizational citizenship behavior is 0.475 which according to the result of testing hypothesis 4.1 , it decreases to 0.132 through inserting spiritual intelligence to 0.132 . In fact, in $95 \%$ confidence level, the impact of workplace spirituality on organizational citizenship behavior becomes insignificant and, on the other hand, customer - oriented organizational citizenship behavior influenced by spiritual intelligence would increase to 0.530. In turn, spiritual intelligence variable acts as the second independent variable. Based on the results of testing hypothesis 4.2, through spiritual intelligence; workplace spirituality impacts on customer - oriented organizational citizenship behavior of $\mathrm{X}$ insurance company employees positively. The extent of impact by workplace spirituality on organizational citizenship behavior is 0.415 which according to the result of testing hypothesis 4.1 , it decreases to 0.132 through inserting spiritual intelligence to 0.132 . According to the results of testing hypotheses 4.1 and 4.2 and the results of testing other hypotheses, one can say that by increasing spiritual intelligence and workplace spirituality, the expression of customer - oriented organizational citizenship behavior by employees would increase (hypotheses $2 \& 3$ ). If spiritual intelligence is not considered, the development of workplace spirituality helps the improvement of customer - oriented organizational citizenship behavior (hypothesis 3) while if spiritual intelligence is considered, the development of workplace spirituality cannot alone help the improvement of customer - oriented organizational citizenship behavior (hypotheses $2 \& 4.1$ ). it makes the impact of workplace spirituality on customer - oriented organizational citizenship behavior insignificant (hypothesis 4.2) and workplace spirituality can improve customer - oriented organizational citizenship behavior through influencing on spiritual intelligence (hypotheses $1 \& 4.2$ ).

The results of $t$ single sample test show that the level of $X$ insurance company employees' spiritual intelligence is ideal and the experience of workplace spirituality for employees undesired. Concerning the results of testing hypotheses 4.1 and 4.2, one can say that if the level of spiritual intelligence is low, customer - oriented organizational citizenship behavior would increase by rising both spiritual intelligence and workplace spirituality. Higher level of spiritual intelligence in customer - oriented organizational citizenship behavior is mostly influenced by rising workplace spirituality while there is also workplace spirituality development since under such circumstances, workplace spirituality through spiritual intelligence would impact on customer - oriented organizational citizenship behavior. As mentioned in literature, expressing customer oriented organizational citizenship behavior by employees has fruitful outcomes especially for organizations and customers and also for 
employees. Although such behaviors are cross - role and are not considered as official tasks of employees, developing and respecting them by managers in service sector and inserting such behaviors in employees' performance appraisal seems important. Since enjoying spiritual intelligence impacts on employees' customer oriented organizational citizenship behavior positively, it is suggested that managers consider it in attracting and selecting needed manpower. Likewise, it is suggested the managers pay attention to workplace spirituality and spiritual intelligence in training plans and improving their own human resources.

\section{Acknowledgment}

Present study was supported by Insurance Research Center, affiliated to the Central Insurance of the Islamic Republic of Iran.

\section{References}

Ashmos, D.P. \& Duchon, D. (2000). Spirituality at work: Definition, measures. Assumption and Validity Clamims, Paper Presented at the Academy of Management, Toronto.

Bitner, M. J. (1990). Evaluating service encounters: the effects of physical surroundings and employee responses. The Journal of Marketing, 69-82.

Bowen, D.E. \& Lawler, E.E. (1992). The empowerment of service workers: what, why, how and when. Sloan Management Review, 33, 31-39.

Brady, M.K., \& Cornin, J. (2001). Customer orientation: effect son customer service perceptions and outcome behaviors. Journal of Service Research, 3, 241-251.

Carlson, J. (1987). Moments of Truth. Sydney: Harper and Row.

Conger, J. A. (1994). Spirit at work: Discovering the spirituality in leadership. San Francisco: Jossey-Bass.

Dimitriades, Z. S. (2007). The influence of service climate and job involvement on customer-oriented organizational citizenship behavior in Greek service organizations: a survey. Employee Relations, 29(5), 469-491.

Dunlap, B. J., Dotson, M. J., \& Chambers, T. M. (1988). Perceptions of real-estate brokers and buyers: A sales-orientation, customer-orientation approach. Journal of Business research, 17(2), 175-187.

Emmons, R. A. (2000). Is spirituality an intelligence? Motivation, cognition, and the psychology of ultimate concern. The International Journal for the Psychology of Religion, 10(1), 3-26.

Farhangi, A. A., Fatahi, M., Vasegh, B., \& Nargesian, A. (2006), workplace spirituality and its role in improving organizational citizenship behavior. Management Culture, 13, 5 - 36 .

Farhangi, A. A., Fatahi, M., Vasegh, B., \& Nargesian, A. (2009). Transformational leadership predicting intelligence, studying the relationship between spiritual intelligence, emotional intelligence and transformational leadership. Iranian Management Science Quarterly, 15, 31 - 57.

Fatahi, M. (2007). Studying the impacts of workplace spirituality on organizational citizenship behavior and its relation to customer loyalty and service quality in Social Welfare Organization, M. A. thesis, University of Tehran, Management School.

Fontana, D. (2003) Psychology, Religion and Spirituality. ABPS Blachwell.

George, M. (2006). How Intelligence are you...Really? From IQ to EQ to SQ, With a Little Intuition along the way. Training \& Management Development Methods, 20(4), 425-436.

Ghaseminejad, H. (2008). Customer - orientation and the necessity of respect to client. Lean Entrepreneur Journal, 5, $57-62$.

Gibbons, P. (2000). Spirituality at work: Definitions, measures assumptions, and validity claims. Paper presented at the academy of management annual meetings. Toronto.

Gronroos, C. (1985). Internal marketing: theory and practice. Services Marketing in a Changing Environment, American Marketing Association, Chicago: IL, 7-41.

Habibpour, K. \& Safari, R. (2009), SPSS comprehensive application guide in surveys (analyzing quantitative data), Motefakaeran Publications, Tehran. 
Hartline, M.D., Maxham, J.G. \& McKee, D.O. (2000). Corridors of influence in the determination of customer-oriented strategy to customer contact service employees. Journal of Marketing, 64, 35-50.

Hoffman, K.D. \& Ingram, T.N. (1992). Service provider, job satisfaction and customer-oriented performance. Journal of Services Marketing, 6(2), 68-78.

Kelley, S.W. (1992). Developing customer orientation among service employees. Journal of the Academy of Marketing Science, 27-36.

Kennedy, M. H. (2001). Spirituality in the workplace: An empirical study of this phenomenon among adult graduates of a college degree completion program(Doctoral dissertation, Nova Southeastern University).

Kinjerski, V. M., \& Skrypnek, B. J. (2004). Defining spirit at work: finding common ground. Journal of Organizational Change Management, 17(1), 26-42.

Knox, A. (2007). Never the twain shall meet? The customer-oriented bureaucracy and equal employment opportunity in service work. Management Research News, 30(3), 216-227.

Krejcie, R.V. \& Morgan, D.W. (1970). Determining sample size for research activities. Educational and Psychological Measurement, 607-610.

McMullen, B. (2003). Emotional intelligence. British Medical Journal, 326(7381), S19.

Milliman, J., Czaplewski, A. J., \& Ferguson, J. (2003). Workplace spirituality and employee work attitudes: An exploratory empirical assessment. Journal of organizational change management, 16(4), 426-447.

Mitroff, I. \& Denton, E. (1999). A Spirituality Audit of Corporate America: A Hard Look at Spirituality, Religion, and Values in the Workplace. Son Francisco, Jossey-Bass.

Mitroff, I. \& Denton, E. (1999). A Study of Spirituality in the Workplace. Sloan Management Review, 83-92.

Momeni, M., \& Ghayumi, A. (2010). Statistical Analyses by using SPSS. Moalef Publications, Tehran.

Nasel, D. (2004). Spiritual orientation in relation to spiritual intelligence: A consideration of traditional Christianity and New Age/individualistic spirituality(Doctoral dissertation, University of South Australia).

Neal, J. A., Lichtenstein, B. M. B., \& Banner, D. (1999). Spiritual perspectives on individual, organizational and societal transformation. Journal of Organizational Change Management, 12(3), 175-186.

Neal. J. (2004). www.spiritatwork.org/library/SpiritualIntelligenceAssessment.pdf.

Organ, D. W. (1988). Organizational citizenship behavior: The good soldier syndrome (Vol. 133). Lexington, MA: Lexington books.

Podsakoff, P. M., Ahearne, M., \& MacKenzie, S. (1997). Organizational citizenship behavior and the quantity and quality of work group performance. Journal of applied psychology, 82(2), 262-270.

Rastegar, A. A. (2010). Spirituality in Organization with a Psychological Approach. Qom, Religions University Publications [In Persian].

Robbins, S.P. (2005). Essentials of Organizational Behavior. $8^{\text {th }}$ ed., Prentice-Hall.

Saghravani, Sima and Ghayour, Morteza (2009), Spirituality, self - flourish and spiritual intelligence in workplace, Specialized - Research - Scientific Quarterly of Management Group at Imam Reza University, 6. 27 - 31 [In Persian].

Sarmad, Z., Bazargan, A., \& Hejazi, E. (2008). Research Methods in Behavioral Science. Agah University, Tehran.

Sisk, D. (2008). Engaging the spiritual Intelligence of gifted student to build global awareness in classroom. Academic Research Library, 30, 24-30.

Sohrabi, F. (2008). The basics of spiritual intelligence. Mental Health Quarterly, 1, $14-18$.

Vaughan, F. (2003). What is spiritual intelligence? Journal of Humanistic Psychology, 42(2), 16-33.

Yazdani, H. R., Kazemi, M. R., \& Salimi, G.R. (2010). Studying the role of spirituality in the relationship between organizational justice and spirituality outcomes. Management Outlook Commercial Management, 3, 117 - 133.

Zarei Matin, H. (2009). Advanced Organizational Behavior Management, Tehran, Agah Publications.

Zohar, D. \& Marshall, I. (2000). SQ: Spiritual Intelligence, The Ultimate Intelligence. London: Bloomsbury. 